\title{
'N VERGELYKING TUSSEN \\ KINDERPSIGIATRIESE VERPLEGING IN SUID-AFRIKA EN SAN FRANCISCO
}

\section{L. van Rhyn}

\section{Opsomming}

In die Republiek van Suid-Afrika is die dienslewering aan kinders - veral Swart en ander minder bevoorregte kinders - met psigiatriese versteurings beperk en ontoereikend. Die praktyk van die verpleegkundige in die kinderpsigiatriese veld is vaag en onderontwikkel. Daar is ook weinig verpleegkundiges in Suid-Afrika wat oor die kennis en vaardighede beskik om riglyne vir hierdie praktyk daar te stel.

'n Kwalitatiewe veldondersoek is in Suid-Afrika en San Francisco gedoen om die stand van die huidige verpleegpraktyk in kinderpsigiatrie te analiseer en te beskryf. ' $n$ Vergelyking word tussen die verpleegpraktyk in Suid-Afrika en San Francisco getref. Uit die resultate blyk dit dat verpleegkundiges in San Francisco akademies beter gekwalifiseerd was as hul kollegas in Suid-Afrika. Baie ooreenkomste met betrekking tot terapeutiese vaardighede is aangetref.

Probleme in die praktyk in Suid-Afrika sluit onder meer rigiede sisteme, onvoldoende erkenning, swak posbeskrywings en onvoldoende supervisie in. Talle verpleegkundiges wat in kinderpsigiatrie gespesialiseer het, het as gevolg van frustrasies en probleme in die praktyk di) veld verlaat. Dit is noodsaaklik dat daar aandag aan hierdie probleme gegee sal word sodat verpleegkundiges wat vir hierdie veld gewerf word, behou kan word.

\section{Summary}

The provision of services to children with psychiatric disorders in the Republic of South Africa - especially black and underpriviliged children - is limited and inadequate. The practice of the nurse in the field of child psychiatry is vague and undeveloped and there are few nurses in South Africa with the knowledge and skills to set guidelines for this area of practice.

A qualitative field study was undertaken in South Africa and San Francisco to analyze, describe and compare the situation in regard to contemporary nursing practice in child psychiatry. The result showed that nurses in San Francisco were academically better qualified than their collegues in South Africa, while many similarities regarding theraputic skills were found.

Problems in South Africa included rigid systems, insufficient recognition, poor job descriptions and inadequate supervision. Large numbers of nurses who are specialized in child psychiatry have left the health services as a result of frustration and problems encountered in practice. These problems must be addressed in order to retain nurses recruited to this field of practice.

\section{INLEIDING}

In die Republiek van Suid-Afrika is die dienslewering aan kinders met psigiatriese versteurings beperk en ontoereikend. Die beskikbaarheid van geestesgesondheids-fasiliteite, aan veral
Swart- en ander minderbevoorregte kinders is onvoldoende. Voorts is daar geen koördinering van dienste op streekof nasionale vlak om in die behoeftes van kinders te voorsien nie. Die bestaande koördinerende liggame op gesondheids-, maatskaplike- en onderwysgebied skakel nie onderling om kinderpsigiatriese dienste te bevorder nie (Verslag van die Komitee van Ondersoek na Kindergeestesgesondheidsversorgingsdienste 1988:vii).

'n Verkennende ondersoek deur die navorser het aangetoon dat daar geen riglyne in die Republiek van Suid-Afrika vir die praktyk van die verpleegkundige in die kinderpsigiatriese veld bestaan nie. Die praktyk van die verpleegkundige met betrekking tot kinderpsigiatrie is vaag en onderontwikkel. Hierdeur kan die kennis en vaardighede van verpleegkundiges nie optimaal benut word nie en word die dienslewering aan kinders met psigiatriese versteurings verder verswak. Die situasie word gekompliseer deurdat daar weinig verpleegkundiges in Suid-Afrika is wat oor die kennis en vaardighede beskik om riglyne vir hierdie praktyk daar te stel. Aangesien die kinderpsigiatriese fasiliteite in Suid-Afrika baie beperk is en daar ook baie min verpleegkundiges in heirdie fasiliteite funksioneer, is ' $n$ gedeelte van die navorsingsprojek in San Francisco gedoen om sodoende riglyne vir die verpleegkundige praktyk in Suid-Afrika te bepaal. Die dataversamelingsverloop verduidelik hoe hierdie proses plaasgevind het.

\section{METODOLOGIE EN ONTWERP VAN DIE STUDIE}

'n Kwalitatiewe veldondersoek is as 'n toepaslike navorsingsmetode vir hierdie studie gekies. 'n Veldondersoek is deur middel van deelnemende waarneming, ongestruktureerde- en semi-gestruktureerde onderhoude en die analise van dokumente (kurrikulums) uitgevoer (Wilson 1989:416).

Volgens Marshall en Rossman (1989:78) kan kwalitatiewe navorsing verkennend, verklarend, beskrywend of voorspellend van aard wees. Die betrokke navorsing is ' $n$ beskrywende en verkennende studie. Daar is egter ook 'n vergelyking tussen die verpleging van kinders met 
psigiatriese versteurings in San Francisco en die verpleging van soortgelyke kinders binne die Suid-Afrikaanse konteks getref.

'n Intensiewe literatuurstudie met betrekking tot kinderpsigiatriese versteurings en terapeutiese tussentredes in kinderpsigiatriese verpleging is ook gedoen.

\section{DOELSTELLINGS VAN DIE STUDIE}

Die doelstellings van die studie was om:

- die stand van die huidige verpleegpraktyk in kinderpsigiatrie te analiseer en te beskryf - nasionaal en internasionaal ${ }^{1}$;

- verskeie kurrikulums te analiseer ten einde die aard van verpleegkundige opleiding met betrekking tot kinderpsigiatrie vas te stel;

- 'n model vir die verpleging van kinders met psigiatriese versteurings in Suid-Afrika voor te stel.

Die eerste doelstelling is bereik deur die volgende aspekte van die verpleegkundige se praktyk te ondersoek:

- die terapeutiese vaardighede waaroor sy $^{2}$ beskik;

- haar funksies, verantwoordelikhede en tussentredes as lid van 'n multiprofessionele span;

- haar professionele en akademiese agtergrond;

- die bestaande hulpbronne en ondersteuningsisteme;

- die tipe kinderpsigiatriese versteurings waarby sy betrokke is;

- tekortkominge en probleme.

Weens die omvang van die studie word slegs die belangrikste resultate van die eerste doelstelling in hierdie artikel bespreek. Die derde doelstelling word in 'n opvolgartikel bespreek.

\section{DATAVERSAMELINGSVERLOOP}

Die data is in drie stadiums versamel. In figuur 1 word 'n uiteensetting verskaf.

\section{STADIUM I}

STADIUM II

STADIUM III

\begin{tabular}{|c|c|c|}
\hline Suid-Afrika & San Francisco & Suid-Afrika \\
\hline $\begin{array}{l}\text { Aanvanklike ondersoek } \\
\text { - VERKENNING } \\
\text { deur middel van } \\
\text { deelnemende } \\
\text { waarneming en } \\
\text { ongestruktureede } \\
\text { onderhoude } \\
\text { - Literatuurstudie }\end{array}$ & $\begin{array}{l}\text { - VERKENNING } \\
\text { deur middel van } \\
\text { deelnemende } \\
\text { waarneming en } \\
\text { ongestruktureede } \\
\text { onderhoude } \\
\text { VERGELYKING } \\
\text { RIGLYN I } \\
\text { (Bylaag A) } \\
\text { deur middel van } \\
\text { semi-gestruktureerde } \\
\text { onderhoude } \\
\text { - Analise van } \\
\text { magister-kurrikulum } \\
\text { Aanvuilende } \\
\text { literatuurstudie }\end{array}$ & $\begin{array}{l}\text { - OPVOLGENDE } \\
\text { VERLYKING } \\
\text { - KONTROLE } \\
\text { ten opsigte van temas, } \\
\text { ooreenkomste en } \\
\text { verskille } \\
\text { RIGLYN II } \\
\text { (Bylaag A) } \\
\text { deur middel van } \\
\text { semi-gestruktureerde } \\
\text { onderhoude } \\
\text { - Analise van pre- } \\
\text { registrasle en SARV } \\
\text { (gespesialise } \\
\text { n a r e g i s t r a s i e ) } \\
\text { kurrikulums }\end{array}$ \\
\hline
\end{tabular}

Figuur 1

Die data versamelingsverloop

\section{DIE ONTLEDINGSEENHEID}

Al die verpleegkundiges (12) wat by die kinderpsigiatriese fasiliteite in San Francisco ${ }^{3}$ gedurende die tydperk: Februarie tot Mei 1989 werksaam was, is by die studie betrek. Daar is gerieflikheidshalwe op hierdie tydperk besluit.

By die Departement Verpleegkunde van die Universiteit van Kalifornië, San Francisco (UKSF) is twee dosente in kinderpsigiatriese verpleging sowel as vyf magister-en twee doktorale studente wat vir hierdie kursus gedurende die eerste helfte van 1989 geregistreer was, ook by die studie ingesluit.

In Suid-Afrika is alle verpleegkundiges (19) wat in provinsiale kinderpsigiatriese fasiliteite 4 gedurende die eerste ses maande van 1991 werksaam was, in die studie ingesluit. Hierdie tydperk is gerieflikheidshalwe geselekteer.

\section{DATAVERWERKING}

Die data wat vanuit deelnemende waarneming en semi-gestruktureerde onderhoude verkry is, is volgens die volgende stappe geanaliseer:
- Data is in kategorie- volgens die frekwensie van voorkoms, die intuïtiewe oordeel van die navorser (Burns en Grov) 1987:83) en kategorieë vanuit die literatuur geklassifiseer.

- Temas is daarna op grond van herhalende ooreenkomste geïdentifiseer (Burns en Grov) 1987:84; en Polit en Hungler 1987:357).

- Frekwensietabelle is gebruik om die frekwensie van ooreenkomste en temas aan te dui.

- Laastens volg 'n strukturele verduideliking van bevindinge.

\section{BEVINDINGS EN INTERPRETASIE VAN DATA}

\section{Sosiografiese data}

$\mathrm{Al}$ die respondente met die uitsondering van een manspersoon in San Francisco (SF) was vroulik. Amper die helfte $(47,6 \%)$ van die respondente in SF was tussen 31 en 40 jaar oud. In die Republiek van Suid-Afrika (RSA) was die verspreiding baie eweredig tot op die ouderdom van 50 jaar. In SF sowel as in

\footnotetext{
${ }^{1}$ San Francisco.

${ }^{2}$ Die vroulike aanspreekvorm word gebruik aangesien feitlik al die respondente vroulik was.

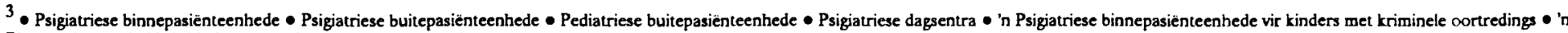
Binnepasiënteenheid vir kinders met substansgebruikversteurings.

4 • Psigiatriese binnepasiënteenhede • Psigiatriese buitepasiēnteenhede • 'n Psigiatriese dagsentra.
} 
die RSA was daar slegs een persoon bo die ouderdom van 51 jaar.

\section{Hoogste akademiese kwalifikasie}

Die akademiese kwalifikasies van verpleegkundiges in kinderpsigiatrie in SF was baie hoër as dié in die RSA. In SF het alle respondente oor 'n baccalaureusgraad beskik en almal was besig met, of het reeds 'n nagraadse kwalifikasie verwerf. In die RSA het 17 respondente $(89,4 \%)$ slegs oor 'n kinderpsigiatriese praktyk gehad terwyl 10 respondente $(52,6 \%)$ in die RSA oor meer as vyf jaar praktykondervinding beskik het. Agt respondente (38\%) in SF en twee $(10,5 \%)$ in die RSA het oor meer as 10 jaar praktykondervinding beskik (kyk figuur 2).

Aard van opset en verspreiding van verpleegkundiges

In die RSA was die meeste respondente $(57,8 \%)$ in buitepasiënteenhede

\begin{tabular}{|c|c|c|c|c|}
\hline \multicolumn{5}{|c|}{$\begin{array}{l}\text { Tabel 1 } \\
\text { Hoogste akademiese kwalifikasie }\end{array}$} \\
\hline \multirow{2}{*}{$\begin{array}{l}\text { Akademiese } \\
\text { Kwalifikasie }\end{array}$} & \multicolumn{2}{|c|}{$\begin{array}{c}S F \\
(N=21)\end{array}$} & \multicolumn{2}{|c|}{$\begin{array}{c}\text { RSA } \\
(N=19)\end{array}$} \\
\hline & frekwensie & $(\%)$ & frekwensie & (\%) \\
\hline $\begin{array}{l}\text { Diploma: } 3 \text { jaar } \\
\text { Diploma: } 3 \text { jaar } \\
\text { Diploma: } 4 \text { jaar } \\
\text { Na-registrasie diploma: Kinder- } \\
\text { psigiatrie } \\
\text { Baccalaureusgraad } \\
\text { Besig met Magisterstudie } \\
\text { Magistergraad } \\
\text { Besig met doktorale studie } \\
\text { Doktorsgraad }\end{array}$ & $\begin{array}{r}5 \\
12 \\
2 \\
2\end{array}$ & $\begin{array}{r}(23,8) \\
(57,2) \\
(9,5) \\
(9,5)\end{array}$ & $\begin{array}{l}4 \\
6 \\
1 \\
6 \\
1 \\
1\end{array}$ & $\begin{array}{r}(21,1) \\
(31,5) \\
(5,3) \\
(31,5) \\
(5,3) \\
(5,3)\end{array}$ \\
\hline
\end{tabular}

werksaam terwyl die meeste respondente in SF (48\%) in binnepasiënteenhede werksaam was (kyk tabel 2).

\section{Vorige ondervinding in algemene psigiatrie}

In SF sowel as in die RSA het die grootste groep verpleegkundiges in die kinderpsigiatriese veld minder as vyf jaar praktykondervinding in die algemene psigiatriese veld gehad.

\section{Die muitiprofessionele span}

In SF sowel as die RSA het al die respondente as lede van 'n multiprofessionele span gefunksioneer. Die volgende professionele persone is meestal deur al die respondente as 'n spanlid geïdentifiseer. Naamlik die:

- verpleegkundige;

- psigiater;

- sielkundige en

- maatskaplike werker. diploma opleiding beskik terwyl daar slegs twee gegradueerde verpleegkundiges $(10,6 \%)$ in die kinderpsigiatriese praktyk was (kyk tabel 1).

\section{Professionele kwalifikasies}

Die aard van die professionele kwalifikasies is nie by die respondente in SF ondersoek nie aangesien verpleegkundige opleiding in SF en die RSA so verskil dat 'n vergelyking daarvan irrelevant is. Die respondente in die RSA was almal as algemene-, psigiatriese- en verloskundige verpleegkundiges geregistreer. Agt respondente het gemeenskapsverpleegkunde, een verpleegonderwys en een pediatriese verpleegkunde as kwalifikasie gehad.

\section{Spesialisasie in kinderpsigiatrie}

In die RSA het slegs ses van die 19 respondente $(31,5 \%)$ in kinderpsigiatriese verpleging gespesialiseer. Daarenteen het 13 van die 21 respondente (62\%) in SF ook in kinderpsigiatriese verpleging gespesialiseer. Vyf van die oorblywende agt respondente in SF was magistergraad studente wat besig was om in die veld te spesialiseer.

Praktykondervinding in kinderpsigiatrie

In SF het 16 respondente ( $76 \%$ ) meer as vyf jaar ondervinding in die

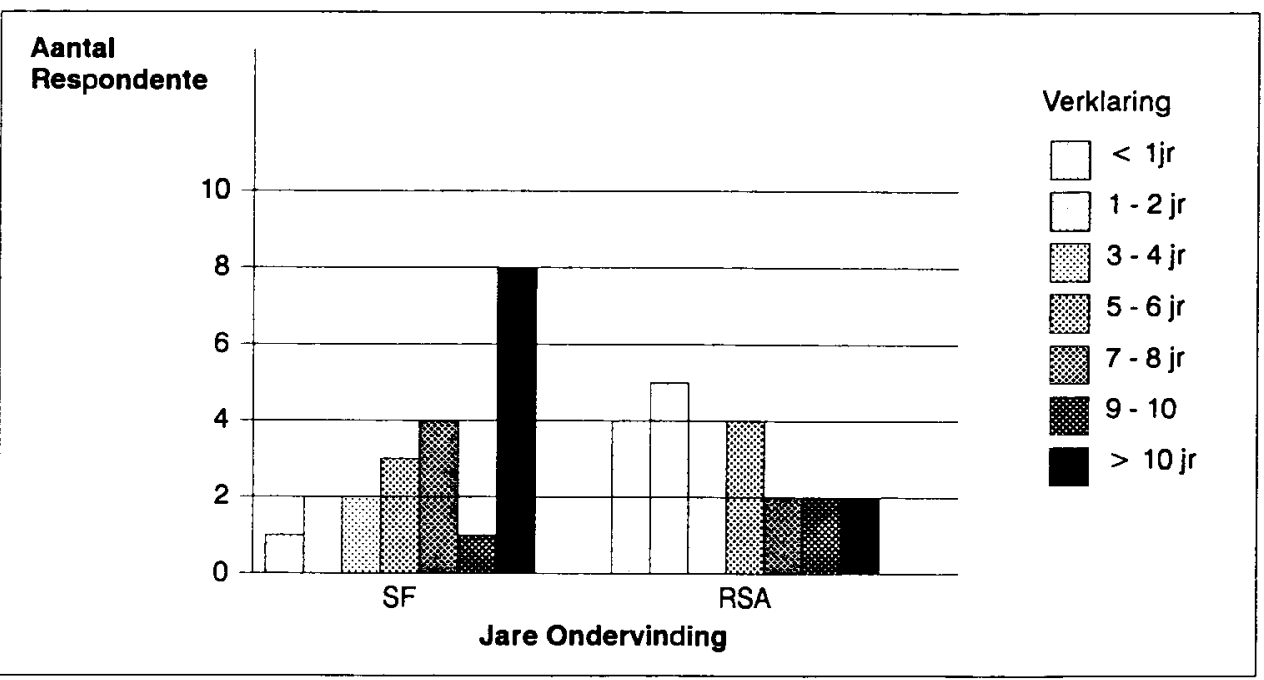

Figuur 2

Praktykondervinding

Tabel 2

Aard van opset en verspreiding van verpleegkundiges

\begin{tabular}{|l|r|r|r|r|}
\hline \multirow{2}{*}{ OPSET } & \multicolumn{2}{|c|}{ SF } & \multicolumn{2}{c|}{ RSA } \\
& (N = 21) & \multicolumn{2}{c|}{ (N) } \\
\cline { 2 - 5 } & frekwensie & (\%) & frekwensie & \multicolumn{1}{c|}{ (\%) } \\
\hline Psigiatriese binnepasiënteenheid & 8 & $(38,1)$ & 7 & $(36,9)$ \\
Psigiatriese buitepaslënteenheid & 5 & $(23,8)$ & 11 & $(57,8)$ \\
Pediatriese buitepasiënteenheid & 2 & $(9,5)$ & & $(5,3)$ \\
Dagsentrum & 2 & $(9,5)$ & & \\
Binnepasiënteenheid vir kinders & 1 & $(4,8)$ & & \\
met kriminele oortredings & 1 & $(4,8)$ & & \\
Binnepasiënteenheid vir kinders & & & & \\
met substansgebruikversteurings & & $(9,5)$ & & \\
Departement Verpleegkunde & & & & \\
(UKSF) & & &
\end{tabular}


In die RSA is die arbeidsterapeut deur meer respondente $(75 \%)$ as in SF (33\%) as spanlid geidentifiseer, terwyl die onderwyser weer deur meer respondente in SF (67\%) as in die RSA (37\%) as spanlid aangewys is. Slegs een persoon $(\mathbf{N}=21)$ in SF het die dominee as ' $n$ spanlid beskou, terwyl tien persone ( $N=$ 19), dit wil sê $53 \%$ in die RSA, die dominee as lid van die multiprofessionele span aangewys het. Die kunsterapeut en die musiekterapeut is onderskeidelik deur die respondente in SF en die RSA as bykomende spanlede aangedui.

Die rol wat die verpleegkundige binne spanverband vervul, is as volg deur 80 tot $100 \%$ van die respondente in die RSA en SF geïdentifiseer:

- diagnostiese beraming van die pasiënt en die gesin;

- gevallevoordragte;

- die beplanning van behandeling;

- terapie;

- voorsien terugvoer aan ander spanlede met betrekking tot die gelewerde terapie sowel as die vordering van die pasiënt.

Koördinering en skakeling met die ander spanlede word gedoen deur middel van:

- multiprofessionele spanvergaderings;

- beplanningsvergaderings;

- personeelvergaderings;

- groepsupervisie;

- formele en informele konsultasie.

Die inisiële beraming van die kind en die gesin

\section{Republiek van Suid-Afrika}

\section{Binnepasiënteenhede}

In die binnepasiënteenhede en die dagsentrum is die inisiële beraming van die kind en die gesin nie deur die verpleegkundige gedoen nie. Hierdie beraming geskied in die buitepasiënteenhede waarna die kind na 'n binnepasiënteenheid of 'n dagsentrum verwys word. Die span in die buitepasiënteenheid besluit oor die doelwitte van behandeling en hoe dit bereik kan word. Die mate waartoe die verpleegkundige van die binnepasiënteenheid ten opsigte van die inisiële beraming en die toelating van die kind betrek word, varieer van eenheid tot eenheid. In een geval word die verpleegkundige glad nie betrek nie terwyl sy in 'n ander geval die beramingsonderhoud deur 'n eenrigtingspieël dophou en daarna neem sy aan die spanbespreking deel. In die laaste geval funksioneer dieselfde verpleegkundige in 'n gekombineerde binne- en buitepasiënteenheid en sy word slegs tydens die besluitneming oor die kind se toelating betrek, maar is egter baie selde by die inisiële beraming van die kind en die gesin betrokke.

\section{Buitepasiënteenhede}

In die buitepasiënteenhede doen al die verpleegkundiges hierdie aanvanklike beraming. Die verpleegkundige gebruik dieselfde instrument as al die ander spanlede om hierdie beraming uit te voer. Hierdie instrument verskil van eenheid tot eenheid, maar die inligting wat hierdeur verkry word is basies by alle eenhede dieselfde. Die volgende data word gewoonlik ingesluit:

- epidemiologiese data;

- redes vir verwysing;

- sosiale omstandighede (behuising, werksomstandighede, finansiële posisie en ontspanning);

- presenterende probleem of hoofklagte soos deur die kind en die ouers ervaar;

- ouers se verwagtinge;

- gesinsfunksionering en familiegeskiedenis;

- huweliksgeskiedenis van die ouers;

- algemene geskiedenis van die gesin van oorsprong;

- geboorte- en ontwikkelingsgeskiedenis en huidige funksionering van die kind;

- die kind se kliniese beeld;

- skool/kleuterskoolgeskiedenis;

- bevindinge wat tydens 'n fisieke ondersoek van die kind verkry is.

\section{Die beramingsproses}

Die proses van beraming stem in al die eenhede ooreen. Aanvanklik word die hele gesin en daarna die individuele kind evalueer. Tydens die beraming van die gesin neem die kind óf deel aan die onderhoud of take word veral aan die baie jong kind gegee terwyl sy gedrag deurentyd waargeneem word. Tydens die gesinsberaming word die volgende aspekte geëvalueer naamlik die gesinsdinamika, interpersoonlike verhoudings, die ouers se insig in die kind se probleem en die funksionering van die gesin. Tydens die individuele beraming van die kind (veral die jong kind) word die kliniese beeld en die gedrag met behulp van spelobservasie geëvalueer.

\section{$\underline{\text { San Francisco }}$}

In SF is die model wat tydens die inisi-le beraming van die kind en die gesin gebruik word, ondersoek.

Die volgende modelle is tydens die beraming van die gesin gebruik:

- die strukturele sisteembenadering;

- die psigodinamiese model;

- 'n kombinasie van die strukturele en strategiese familieterapiebenaderings.

Die modelle wat vir die beraming van die kind gebruik is, was:

- 'n ontwikkelingsteoretiese model;

- 'n psigodinamiese model;

- 'n mediese model;

- 'n biopsigososiale model.

In Suid-Afrika kon die verpleegkundige verbaliseer wat sy gedurende die inisiële beraming van die kind doen, maar sy kon dit nie binne 'n sekere raamwerk of model plaas nie.

\section{Die beraming van die omgewing}

\section{Republiek van Suid-Afrika}

Slegs een verpleegkundige $(N=19)$ wat in ' $n$ buitepasiënteenheid in die RSA funksioneer, beraam altyd die omgewing waaruit die kind kom deur tuis- en skoolbesoeke te doen. Die ander 18 verpleegkundiges doen nooit of baie selde tuis-en skoolbesoeke. Die omgewing van die kind word dan deur middel van die volgende hulpmiddels beraam:

- 'n geskiedenisvasstelling;

- tuisbesoeke deur die maatskaplike werker wat terugvoer aan die verpleegkundige gee;

- skoolverslae (skriftelik of telefonies);

- besoeke deur die onderwyser aan die eenheid. 
Tabel 3

Terapeutiese vaardighede

\begin{tabular}{|c|c|c|c|c|c|c|}
\hline Aktiwiteit & $\begin{array}{c}\text { SF } \\
\text { Binne- } \\
\text { pasiënt } \\
N=10\end{array}$ & $\begin{array}{c}\text { RSA } \\
\text { Binne- } \\
\text { pasiënt } \\
\mathbf{N}=7\end{array}$ & $\begin{array}{c}\text { SF } \\
\text { Buite- } \\
\text { pasiënt } \\
\mathbf{N}=7\end{array}$ & $\begin{array}{c}\text { RSA } \\
\text { Buite- } \\
\text { pasiënt } \\
\mathbf{N}=11\end{array}$ & $\begin{array}{c}\text { SF } \\
\text { Dag- } \\
\text { sentrum } \\
N=2\end{array}$ & $\begin{array}{c}\text { RSA } \\
\text { Dag- } \\
\text { sentrum } \\
\mathbf{N}=1\end{array}$ \\
\hline & $\mathbf{f}$ & $\mathbf{f}$ & 1 & 1 & $f$ & $\mathbf{f}$ \\
\hline Individuele psigoterapie & 4 & 1 & 6 & 4 & - & - \\
\hline Groeppsigoterapie & - & - & - & 1 & - & - \\
\hline Spelterapie & 2 & 3 & 7 & 7 & - & - \\
\hline Groepterapie & 8 & 1 & 1 & 6 & 2 & - \\
\hline Familieterapie & 6 & 1 & 7 & 4 & 2 & - \\
\hline Terapeutiese groepe & 6 & 4 & $\cdot$ & 6 & 2 & 1 \\
\hline Gedragsmodifikasie & 5 & 7 & - & 8 & 1 & 1 \\
\hline Milieuterapie & 10 & 7 & - & 3 & 2 & 1 \\
\hline Terapeutiese gesprekvoering & 10 & 7 & 7 & 11 & 2 & 1 \\
\hline Ontspanningsterapie & - & - & - & 7 & $\cdot$ & - \\
\hline Ontspanningsaktiwiteite & 10 & 7 & - & 4 & 2 & 1 \\
\hline Krisistussentrede & 1 & 1 & 2 & 11 & - & 1 \\
\hline Evaluasie van somatiese terapie & 10 & 7 & - & 10 & 1 & 1 \\
\hline Ouerberading & 7 & 5 & 5 & 11 & 2 & 1 \\
\hline Koördinering van sorg & 10 & 7 & 7 & 11 & 2 & 1 \\
\hline Aanleer van sosiale vaardighede & 10 & 7 & - & 8 & 2 & 1 \\
\hline Daaglikse versorging & 10 & 7 & - & - & 2 & 1 \\
\hline Fisieke bedwang & 5 & 3 & - & - & - & 1 \\
\hline Gesondheidsvoorligting & $\cdot$ & 1 & - & 7 & - & - \\
\hline Konsultasie & - & - & 7 & 9 & - & - \\
\hline Programbestuur & 5 & 7 & 6 & - & 2 & 1 \\
\hline $\begin{array}{l}\text { Daarstelling van 'n terapeutiese } \\
\text { verhouding }\end{array}$ & 10 & 7 & 7 & 11 & 2 & 1 \\
\hline
\end{tabular}

Die volgende indikasies vir 'n skoolbesoek is deur die respondente aangedui:

- waarneming van die kind se gedrag in 'n klaskamer;

- skoolweiering deur die kind;

- potensiële skorsing van 'n kind uit 'n skool;

- hulp vir die onderwyser met die hantering van 'n kind;

- 'n ondersoek na die moontlikheid van terugplasing van 'n kind na 'n spesifieke skool.

Die volgende indikasies vir 'n tuisbesoek is deur die respondente geïdentifiseer:

- Die evaluering van die gesinsopset en huislike omstandighede voor 'n eerste besoek.
- Indien sekere familielede weens praktiese redes nie die eenheid kan besoek nie.

- Hulp en ondersteuning aan die ouers ten opsigte van die hantering van die kind.

- Om die moontlikheid van terugplasing na die huis te evalueer.

- 'n Geskiedenis van mishandeling.

- Opvolg om die kind se vordering te evalueer en daaropvolgende terapie toe te pas.

\section{$\underline{\text { San Francisco }}$}

In SF word die beraming van die omgewing waaruit die kind kom deur die maatskaplike werker gedoen en die verpleegkundige is meestal nie hierby betrokke nie. Indien dit wel deur die verpleegkundige gedoen word, word 'n sisteemteoretiese model of Roy se aanpassingsmodel daarvoor gebruik.

\section{Deurlopende evaluering}

Deurgaans word deurlopende evaluering van die kind in SF en die RSA deur verpleegkundiges gedoen. Met die uitsondering van een eenheid in die RSA, geskied hierdie evaluering op grond van 'n globale indruk van die kind se algemene funksionering en gedrag. Aspekte wat onder andere globaal ge-valueer word, is die verbetering van die presenterende probleem; die kind se deelname aan 'n gestruktureerde program; die kind se houding teenoor die ouers; personeel en portuurgroep; die kind se vermoë tot selfsorg; interpersoonlike verhoudings; die kind se kontak met die werklikheid en sy/haar frustrasiedrempel; die gemoedstoestand van die kind; skoolfunksionering en die kind se reaksie op dissipline.

- Voorligting aan ouers en die betrokke kind met betrekking tot die gebruik van voorgeskrewe medikamente.

- Die evaluering van interpersoonlike verhoudinge.

- Die evaluering van die kind en die gesin se funksionering tuis.

- Die evaluering van die gesinstruktuur en -dinamika.

- Die evaluering van die fisiese en die geografiese area waarbinne die gesin woon.

- Die verkryging van kollaterale inligting.
Soos gemeld, is daar een Suid-Afrikaanse eenheid waar die verpleegkundiges 'n formele deurlopende evaluasie van die kind doen. Aspekte waarna opgelet word, is:

\section{Die fisieke toestand}

- voorkoms;

- taal, spraak en gehoor;

- abnormaliteite byvoorbeeld allergieë;

- eetgewoontes;

- slaapgewoontes;

- selfversorging; 
- medikamentgebruik.

\section{Gedrag, spel en emosies}

- dissipline, struktuur en eise byvoorbeeld toetsende gedrag en onttrekking;

- interaksie met portuurgroep en volwassenes;

- algemene gedrag byvoorbeeld aggressie en dryfkrag;

- spel, byvoorbeeld die voor-en afkeure, inisiatief en fantasie;

- persoonlikheidseienskappe byvoorbeeld angstigheid, vrese en selfvertroue.

\section{Spesifieke probleme}

- eetversteurings byvoorbeeld bulimie;

- psigoseksuele gedrag;

- mutisme/woede-uitbarstings;

- leuens/diefstal;

- mannerismes byvoorbeeld gesigtrekkings.

\section{Terapeutiese vaardighede}

Al die terapeutiese vaardighede van die kinderpsigiatriese verpleegkunde is ondersoek en dit word op grond van die frekwensie van voorkoms in tabel 3 weergegee.

\section{Binnepasiënteenhede}

Volgens tabel 3 gebruik al die respondente in SF en die RSA wat in binnepasiënteenhede funksioneer, die volgende terapeutiese vaardighede:

- milieuterapie;

- terapeutiese gesprekvoering;

- ontspanningsaktiwiteite;

- die evaluasie van somatiese terapie;

- die koördinering van sorg;

- die aanleer van sosiale vaardighede;

- die daaglikse versorging van die pasiënt;

- die daarstelling van 'n terapeutiese verhouding.
In die RSA pas al die verpleegkundiges ook gedragsterapie en programbestuur ${ }^{5}$ toe.

Uit tabel 3 is dit duidelik dat, met die uitsondering van individuele psigoterapie, groepterapie en familieterapie daar 'n groot ooreenstemming tussen die respondente in SF en die RSA is ten opsigte van die gebruik van terapeutiese vaardighede al dan nie. Dit is veral groepterapie wat baie meer deur verpleegkundiges in SF as die RSA gebruik word.

\section{Buitepasiënteenhede}

Die volgende vaardighede word deur die feitlik al die respondente in SF en die RSA gebruik:

- die koördinering van sorg;

- ouerberading;

- terapeutiese gesprekvoering;

- konsultasie; en

- die daarstelling van 'n terapeutiese verhouding.

Individuele psigoterapie, spelterapie, familieterapie en programbestuur word deur feitlik alle verpleegkundiges in SF gebruik. Verpleegkundiges in SF, in buitepasiënt- sowel as binnepasiënteenhede, maak dus meer van psigoterapeutiese vaardighede gebruik. Vaardighede wat weer baie deur verple egkundiges in buitepasiënteenhede in die RSA gebruik word, is gedragsmodifikasie, krisistussentrede, die evaluasie van somatiese terapie en die aanleer van sosiale vaardighede.

\section{Dagsentra}

Die respondente wat in dagsentra in SF en die RSA gefunksioneer het, het ook feitlik dieselfde terapeutiese vaardighede toegepas (kyk tabel 3).

Die twee verpleegkundiges in die dagsentra in SF het van groep- en familieterapie gebruik gemaak wat nie deur die verpleegkundige in die RSA toegepas is nie. In die RSA het die verpleegkundige krisistussentrede en fisieke bedwang geïmplementeer terwyl dit nie deur die verpleegkundiges in SF gebruik is nie.

\section{Tipe versteurings}

Daar is gepoog om vas te stel in hoe ' $n$ mate die verpleegkundige by die behandeling van kinders met onderskeie diagnoses betrokke is. Aangesien verskeie instansies nie 'n formele diagnose gemaak het nie, maar die kind se simptome en gedrag behandel het en die frekwensie van die onderskeie versteurings (volgens die DSM-III-R klassifikasie) wisselend was, was dit moeilik om 'n definitiewe patroon vas te stel. In SF wou dit voorkom asof verpleegkundiges meestal kinders met gedrags-, gemoeds- en persoonlikheidsversteurings (veral grenslyn) behandel het. In die RSA was verpleegkundiges meestal by die behandeling van kinders met gedrags en gemoedsversteurings en seksuele molestering betrokke. V-kode versteurings soos ouer-kind probleme en ander familie omstandighede is dikwels deur verpleegkundiges gebruik.

\section{Ondersteuning in die praktyk}

Die ondersteuning wat die respondente in die praktyk ontvang het en wat hul taak vergemaklik het, is deur die volgende persone aangebied:

- die multiprofessionele spanlede;

- mede-verpleegkundiges;

- verpleeghoofde;

- sielkundiges;

- psigiaters.

Ondersteuningsgroepe vir personeel en supervisie was ook as ondersteuningsbronne geïdentifiseer. In SF het 17 respondente $(81 \%)$ self terapie ondergaan en dit het die volgende voordele ingehou:

- verhoogde empatie met die pasiënt;

- 'n begrip van eie onopgeloste probleme;

- 'n groter insig in die terapeutiese proses;

- 'n ervaring dat terapie werklik suksesvol kan wees.

Geen nadele ten opsigte van terapie is deur die respondente gerapporteer nie.

\section{Probleme in die praktyk}

In SF is die volgende probleme in die praktyk deur die respondente geïdentifiseer:

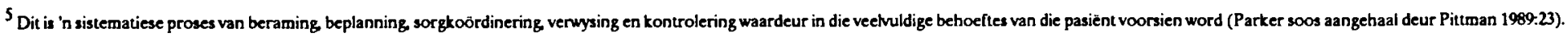


- te veel tyd word aan administratiewe take bestee wat terapeutiese tussentredes nadelig beïnvloed;

- onvoldoende erkenning deur ander spanlede;

- onvoldoende fondse vir die voorsiening van dienste en verpleegkundiges in kinderpsigiatrie.

In die RSA is die volgende probleme in die praktyk aangedui:

- 'n personeeltekort wat tot oneffektiewe funksionering en uitbranding van personeel aanleiding gee;

- min dienste vir kinders in die Kleurling- en Swart bevolkingsgroepe;

- rigiede sisteme wat min verandering toelaat;

- onvoldoende erkenning deur ander spanlede wat die moraal van die verpleegkundige verlaag;

- geen posbeskrywings vir die verpleegkundige nie wat tot onsekerheid lei;

- min ondersteuning deur verpleeghoofde;

- inmenging van die res van die hospitaal;

- onvoldoende supervisie;

- die opname van kinders in volwasse afdelings.

\section{SAMEVATTING EN AANBEVELINGS}

Een kinderpsigiatriese buitepasiënteenheid in die RSA is nie in die studie ingesluit nie, aangesien toestemming vir navorsing nie verkry kon word nie. By hierdie eenheid het ongeveer ses verpleegkundiges gepraktiseer wat die totale aantal verpleegkundiges in die kinderpsigiatriese veld op ongeveer 25 te staan bring (19 is in die studie ingesluit). Alhoewel net ses verpleegkundiges, wat die gevorderde diploma in kinderpsigiatrie gedoen het, ten tye van die navorsing in dié veld gepraktiseer het, dui inligting wat van verskeie respondente verkry is daarop dat altesaam 19 verpleegkundiges in die RSA hierdie kursus suksesvol voltooi het. Een van hierdie persone is die dosent wat tans die betrokke kursus aanbied. Hierdie kursus word slegs by een verpleegkollege in die land naamlik in die Kaapprovinsie aangebied. Verder is daar drie persone wat op nagraadse vlak in kinderpsigiatrie gespesialiseer het. Twee van hierdie drie persone funksioneer in 'n privaatpraktyk en is deeltyds by onderrig betrokke terwyl die derde persoon 'n voltydse onderrigpos beklee. Dus is daar altesaam twee voltydse en twee deeltydse verpleegdosente in die kinderpsigiatriese veld in die RSA beskikbaar. Ten opsigte hiervan wil die navorser aanbeveel dat die volgende maatreëls geïmplementeer word wat 'n groter aantal verpleeg. kundiges in die kinderpsigiatriese veld sal genereer:

- Daar moet ondersoek ingestel word hoekom persone wat in kinderpsigiatrie gespesialiseer het, nie in die betrokke veld praktiseer nie.

- Die gevorderde diploma in kinderpsigiatrie van die Suid-Afrikaanse Raad op Verpleging moet by ten minste een kollege per provinsie aangebied word. Verpleegkundiges wat hierdie kursus suksesvol voltooi het, sowel as kundiges van ander professies, moet waar moontlik vir die opleiding van studente gebruik word.

- Meer verpleegkundiges moet gemotiveer word om op nagraadse vlak te spesialiseer. Sodoende kan meer persone voorberei word om as dosente in kinderpsigiatriese verpleging by universiteite te funksioneer en hierdie persone kan ook vir die praktyk beskikbaar wees wat huidig nie die geval is nie.

- Bevorderingmoontlikhede moet in die praktyk vir die kliniese verpleegspesialis geskep word.

- Probleme en frustrasies in die praktyk moet aandag geniet sodat die verpleegkundiges wat vir hierdie veld gewerf word, behou kan word.

\section{BIBLIOGRAFIE}

ALLWOOD, C.W. (1990). What is to Become of Child Psychiatry in South Africa. Hospital Medicine, April:34-35.

BURNS, N. \& GROVE, S.K. (1987). The Practice of Nursing Research:
Conduct, Critique and Utilization. W.B. Saunders Company, Philadelphia.

JONES, R.N. \& O'BRIEN, P. (1990). Unique Interventions for Child Inpatient Psychiatry. Journal of Psychosocial Nursing, 28(7):29-31.

MARSHALL, C. \& ROSSMAN, G.B. (1989). Designing Qualitative Research. Sage Publications, London.

McKELVEY, R.S. (1988). A Continuum of Mental Health Care for Children and Adolescents. Hospital and Community Psychiatry, 39(8): 870-873.

PITTMAN, D.C. (1989). Nursing Case Management: Holistic Care for the Deinstitutionalized Chronically Mentally Ill. Journal of Psychosocial Nursing, 27(11):23-27.

POLIT, D.F. \& HUNGLER, B.P. (1987). Nursing Research: Principles and Methods, 3rd ed. J.B. Lippincott Co., Philadelphia.

POTHIER, P.C. (1984). Child Psychiatric Nursing. Journal of Psychosocial Nursing, 22(3):11-21.

VERSLAG VAN DIE KOMITEE VAN ONDERSOEK NA KINDER GEESTES GESONDHEIDS VERSORGINGSDIENSTE, Departement van Nasionale Gesondheid en Bevolkingsontwikkeling, Pretoria, 1988.

WILSON, H.S. (1989). Research in Nursing, 2nd ed. Addison-Wesley, Publishing Company, California.

\section{ERKENNINGS}

Ek wil graag my dank aan alle persone wat as respondente aan die navorsing deelgeneem het, betuig.

Die navorsing was deel van 'n doktorale studie wat aan die Universiteit van die Oranje-Vrystaat onderneem was.

LILY VAN RHYN (W.J.C.)

D.Soc.Sc. Nerpleegkunde)

Departement Verpleegkunde Universiteit van die Oranje-Vrystaat 